\title{
THE NITROGEN-ISOTOPIC COMPOSITION OF 1.1 BILLION-YEAR-OLD PORPHYRINS REVEALS OCEANS DOMINATED BY PHOTOTROPHIC BACTERIA
}

\author{
J. J. Brocks ${ }^{1}$, N. Gueneli ${ }^{1}$, A. M. McKenna ${ }^{2}$, N. Ohkouchi ${ }^{3}$, C. J. Boreham ${ }^{4}$, J. Beghine ${ }^{5}$, E. J. \\ Javaux $^{5}$
}

${ }^{1}$ The Australian National University, Australia; ${ }^{2}$ National High Magnetic Field Laboratory, USA; ${ }^{3}$ Japan Agency for Marine-Earth Science and Technology, Japan; ${ }^{4}$ Geoscience Australia; Australia; ${ }^{5}$ University of Liège, Belgium

The oceans of the mid-Proterozoic, 1.8 to $0.8 \mathrm{Ga}$ ago, were devoid of animal-like life. According to recent models, this lack of large multicellular heterotrophs may have been caused by a severe global limitation of the nutrients such as phosphate (Brocks, 2018). Severe nutrient limitation causes low cell densities of primary producers but also gives planktonic cyanobacteria a distinct advantage over microalgae based on their much smaller cell size that promotes nutrient uptake by diffusion. Low cell densities and sizes, in turn, limit the flow of energy and carbon to higher trophic levels, possibly restricting the evolution of energy demanding large organisms (Brocks et al., 2017; Knoll, 2017). This hypothesis is supported by the observation that sterane / hopane ratios are consistently beneath detection limits in the midProterozoic interval $(\mathrm{S} / \mathrm{H}<0.001)$ and only started to surge to modern levels after $\sim 650 \mathrm{Ma}$ ago (Brocks et al., 2017; Hoshino et al., 2017), around the time when eumetazoan animals emerged (Figure 1). However, it is difficult to exclude the possibility that the extremely low sterane abundances are an artefact of unfamiliar Proterozoic degradation processes. The only other known proxy that may record relative abundances of different primary producers is the nitrogen isotopic composition of fossils chlorophylls (porphyrins) (Higgins et al., 2011).

We present the discovery of intact porphyrins (fossils chlorophylls) from 1,100 Ma old marine black shales from Mauritania (Gueneli et al., 2018). The porphyrins, identified at the molecular levek with a 9.4 Tesla Fourier transform ion cyclotron resonance mass spectrometry (FT-ICR MS), are 600 million years older than previous findings. Notably, compound-specific porphyrin nitrogen isotopic compositions $\left(\delta^{15} \mathrm{~N}_{\text {por }}=5.6\right.$ to $10.2 \%$ ) measured at JAMSTEC are heavier than in younger sedimentary sequences, and the isotopic offset $\varepsilon_{\text {por }}$ between sedimentary bulk nitrogen and porphyrins $(-5.1$ to $-0.5 \%$ o is the lowest detected in any ancient sedimentary sequence. The low $\varepsilon_{\text {por }}$ values point to predominantly cyanobacterial primary production with a contribution from anoxygenic phototrophic bacteria based on the presence of 2,3,6- and 2,3,4-trimethyl aryl isoprenoids. However, $\varepsilon_{\text {por }}$ is inconsistent with a significant algal contribution, validating sterane / hopane ratios beneath detection limits of $\mathrm{S} / \mathrm{H}=0.001$ to 0.0002 .

Based on porphyrin and sterane data, planktonic eukaryotic algae, the dominant marine primary producers of the Phanerozoic, did not play a detectable role in mid-Proterozoic oceans (Gueneli et al., 2018). The data supports the view that energy and nutrient limitation at the base of the food web, possibly in combination with low oxygen levels and unstable redox conditions, limited the evolutionary drive towards complex multicellularity and large size. 


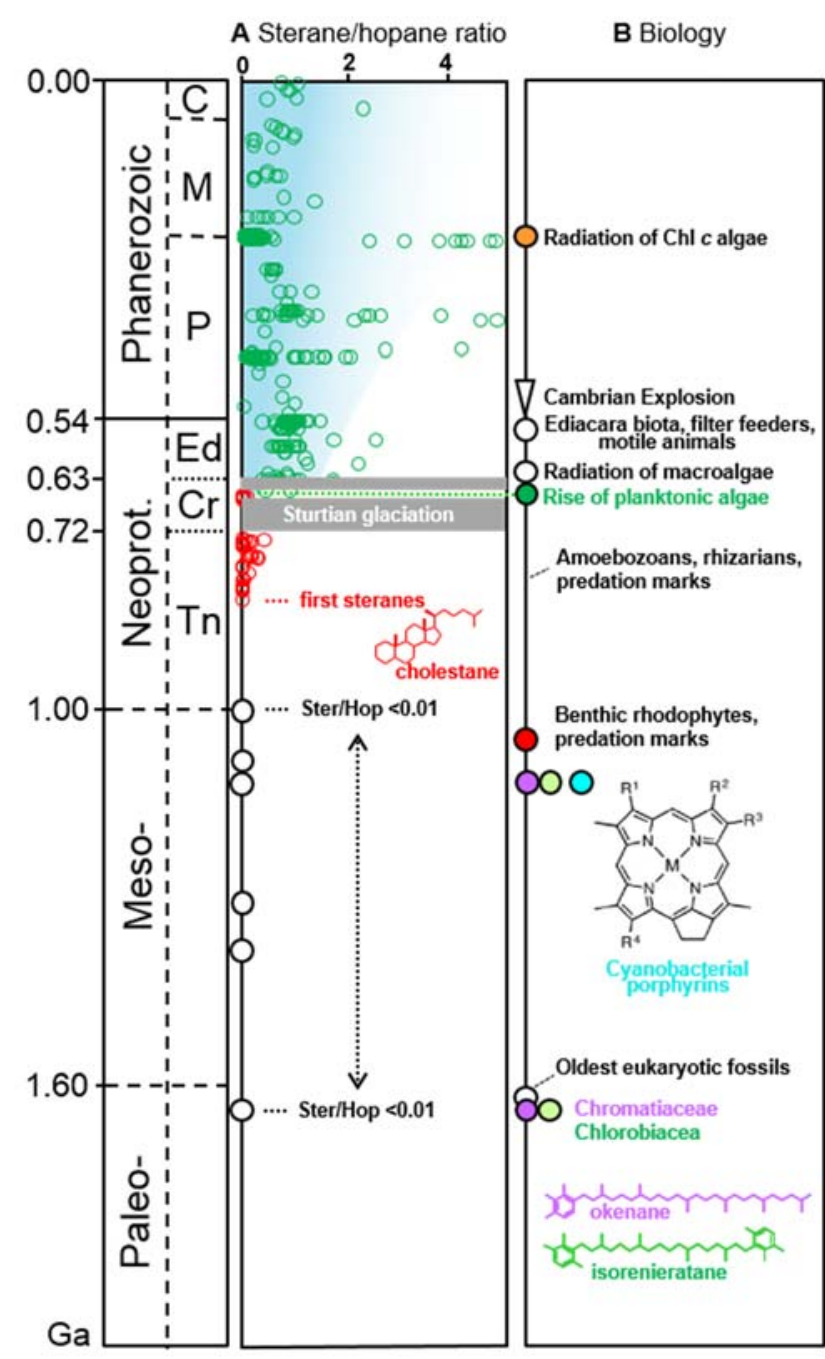

Figure 1. Time chart summarizing biomarker and fossil data. (A) The sterane / hopane ratio as first order estimate of eukaryotic versus bacterial organic matter flux. Green circles represent bitumens comprising $C_{27}$ to $C_{29}$ steranes, red circles a $\sim 100 \%$ cholestane predominance, and unfilled black circles are mid-Proterozoic assemblages where steranes are beneath detection limits while hopanes are present. (B) Biological events. Tn = Tonian, $\mathrm{Cr}=$ Cryogenian, $\mathrm{Ed}=$ Ediacaran periods, $P=$ Paleozoic, $M$ $=$ Mesozoic,$C=$ Cenozoic eras .

Brocks, J.J., 2018. The transition from a cyanobacterial to algal world and the emergence of animals.

Emerging Topics in Life Sciences, 10.1042/etls20180039.

Brocks, J.J., Jarrett, A.J.M., Sirantoine, E., Hallmann, C., Hoshino, Y., Liyanage, T., 2017. The rise of algae in Cryogenian oceans and the emergence of animals. Nature 548, 578-581.

Gueneli, N., McKenna, A.M., Ohkouchi, N., Boreham, C.J., Beghin, J., Javaux, E.J., Brocks, J.J., 2018. 1.1-billion-year-old porphyrins establish a marine ecosystem dominated by bacterial primary producers. Proceedings of the National Academy of Sciences, 10.1073/pnas.1803866115.

Higgins, M.B., Wolfe-Simon, F., Robinson, R.S., Qin, Y., Saito, M.A., Pearson, A., 2011. Paleoenvironmental implications of taxonomic variation among $\delta^{15} \mathrm{~N}$ values of chloropigments. Geochimica et Cosmochimica Acta 75, 7351-7363.

Hoshino, Y., Poshibaeva, A., Meredith, W., Snape, C., Poshibaev, V., Versteegh, G.J.M., Kuznetsov, N., Leider, A., van Maldegem, L., Neumann, M., Naeher, S., Moczydłowska, M., Brocks, J.J., Jarrett, A.J.M., Tang, Q., Xiao, S., McKirdy, D., Das, S.K., Alvaro, J.J., Sansjofre, P., Hallmann, C., 2017. Cryogenian evolution of stigmasteroid biosynthesis. Science Advances 3, e1700887.

Knoll, A.H., 2017. Food for early animal evolution. Nature 548, 528. 